\title{
PENGENDALIAN PEREDARAN GELAP NARKOTIKA OLEH NARAPIDANA DARI DALAM LEMBAGA PEMASYARAKATAN (LAPAS) ${ }^{1}$
}

\author{
Oleh : \\ I Gede Artha (igedeartha27@gmail.com) ${ }^{2}$ \\ I Wayan Wiryawan (iwayanwiryawan@gmail.com)
}

\begin{abstract}
Drug smuggling by high and sophisticated operation mode recently was able reach the prisoner which is as society prison status. Law enforcement officer especially the police in conducted their function as law enforcement to the prisoner that involved in drug smuggling, in disclosure and sttlement their case (investigation step) did not easy because the prisoner was a society in prison encironment. There are two problem in this research : 1. why the conected and correlated of the legal system for drug? 2. Why the drug smuggling is high operation by the prisoner which is as society prison status and to up from in the prison?

The result of this research show that the law enforcement to the doer drug smuggling by the law enforcer. Should faced ethic code profesion society, there for it was impossible for the law the optimize of law enforcement by law enforcer to the doer of drug smuggling in prisoner society such as intern and extern efforts, where the intern effort include increase the coordination function and cooperation between the law enforcement especially with the prison officers.
\end{abstract}

Keywords : Doer of Drug Smuggling, by Prisoner from in the Prison

\section{PENDAHULUAN}

\subsection{Latar Belakang Masalah}

Korban anak bangsa dan generasi penerus bangsa di kalangan remaja dan usia produktif sebagai akibat barang haram narkotika terus berjatuhan. Setiap hari disinyalir memakan korban nyawa manusia di Indonesia rata-rata 50 (lima puluh) orang melayang sia-sia. Indonesia saat ini memang

Karya ilmiah ini merupakan hasil penelitian yang dibiayai dari dana Dipa BLU Program Studi Magister (S2) Ilmu Hukum PPS UNUD dengan SK Direktur Nomor 425/UN.14.4/KU/201, telah dipresentasikan dalam seminar / FGD di Program Magister (S2) Ilmu Hukum pada tanggal 20 Nopember 2015.

2 Para penulis adalah Dosen pada Program Studi Magister (S2) Ilmu Hukum Program Pascasarjana UNUD dan Fakultas Hukum UNUD Denpasar - Bali situasi dan kondisi negara dalam keadaan darurat narkotika. Pencandu dan pengedar obat-obatan terlarang dengan berbagai jenisnya itu macam dan golongannya terus berkembang. Peraturan perundang-undangan yang ada telah gagal dan kewalahan menangani dan mengatasinya. Peredaran narkotika dengan beragam kualifikasi seperti sabu-sabu, heroin, hasish, kokain, ekstasi, morfin serta jenis baru dari racikan, marak terjadi peredarannya tanpa memandang tempat dan waktu.

Modus operandi kejahatannya pun berkembang dari waktu ke waktu. Mulai dari cara-cara konvensional hingga berkembang secara inkonvensional. Dahulunya Indonesia 
hanya sebatas menjadi lintasan atau transit antar benua peredaran narkotika. Bahkan kini di tiap pulau yang ada di nusantara ini, ladang-ladang ganja sebagai bahan baku awal narkotika bertebaran dengan luas hektaran di beberapa lokasi pulau Sumatra. Pengangkutan lewat darat dari Sumatera menuju antar pulau lain di Indonesia seperti tujuan Jawa sering tertangkap oleh Kepolisian dalam kapasitas bukan ukuran kiloan bahkan ton yang diangkut truck kontainer.

Kejahatan di bidang Narkotika dan obat-obatan terlarang (Narkoba) ini modus operandinya mengikuti dan memanfaatkan perkembangan Ilmu Pengetahuan dan Teknologi (IPTEK). Perkembangan dan kemajuan arus globalisasi seperti informasi dan teknologi komunikasi dimanfaatkan secara maksimal oleh sindikat atau jaringan mafia narkotika ini. Tidak salah label yang diberikan untuk tipe kejahatan yang luar biasa (extra ordinary crime), sebagai kejahatan terorganisasi (organized crime), kejahatan terselubung (hidden crime), kejahatan lintas batas negara (transnational crime). Sasaran dan pelaku ini tanpa memandang usia. Obyek sasaran pemakainya merambah pada masyarakat lapisan orang berduit seperti pejabat publik, mahasiswa, pelajar, artis, pengusaha, tidak terlepas pula kalangan masyarakat menengah asalkan status sosial - ekonominya telah mapan.

Suatu fenomena, gejala bahkan telah menjadi fakta sosio-yuridis yang mencengangkan, bahwa salah satu modus yang sulit dipercaya akal sehat telah terungkapnya bahwa peredaran gelap narkotika dikendalikan dari balik jeruji besi alias dari balik tembok penjara, atau sekarang dengan istilah Lembaga
Pemasyarakatan (LAPAS). Pengendali atau actor intelektualisnya notabene adalah orang status masih narapidana atau warga binaan LAPAS. Narapidana ini tidak jarang bekerjasama dengan petugas LAPAS atau Sipir. Narapidana yang bersangkutan secara leluasa dapat mengendalikan bisnis haramnya lewat komunikasi canggih seperti handphone (HP), wartel dalam LAPAS, radio khusus. Untuk itu, dengan komunikasi langsung bersama jaringan bisnis, seperti pengedar, pemakai yang ada di luar LAPAS bahkan dengan jaringan rekanan yang berada di luar negeri.

Beberapa LAPAS besar dan terkenal yang ada di Indonesia seperti Nusa Kambangan, Rutan Salemba, LAPAS Cipinang, LAPAS Pondok Bambu, LAPAS Kalisosok Surabaya, LAPAS Semarang dan LAPAS / RUTAN lainnya di Indonesia, tak terkecuali dan tidak luput termasuk LAPAS dan / atau RUTAN Denpasar yang berlokasi di Kerobokan - Badung, tidak luput menjadi lokasi (locus delicty) peredaran gelap narkotika oleh narapidana bersama beberapa sipir yang ada di dalamnya.

Pelaksanaan eksekusi mati tahap pertama para pengedar dan jaringan sindikat narkotika asal Australia yang terkenal dengan sebutan Bali Nine telah dilakukan pada akhir tahun 2014. Penundaan eksekusi mati tahap dua yang rencananya dilakukan awal tahun 2015 hingga kini masih tertunda. Hal tersebut memicu pro dan kontra akan keberadaan pelaksanana eksekusi mati tertunda sebagai akibat salah satunya para terpidana kembali mengajukan upaya hukum luar biasa berupa Peninjauan Kembali (PK). Disamping disinyalir adanya tekanan pihak negara asing yang warga negaranya termasuk didalamnya 
siap untuk dieksekusi mati, karena Presiden telah menolak permohonan grasi dari para terpidana mati tersebut. Seperti negaranegara Australia, Filipina, Brazilia bersuara lantang kepada Pihak Indonesia melalui saluran diplomasi Departemen Luar Negeri masing-masing

Salah satu terpidana mati yang tertunda eksekusinya yakni : Fredy Budiman, terungkap kembali bahwa ia masih mengendalikan bisnis peredaran gelap narkotika dari balik LAPAS Nusa Kambangan, yang memiliki jaringan Internasional bahkan ia berkomunikasi langsung dengan rekanan bisnis gelapnya yang ada di Belanda, Jerman dan Pakistan (Keterangan langsung Fredy Budiman dengan Wartawan Metro TV pada hari Senin, 13 April 2015, Pukul 19.30 Wita).

Usaha pemerintah Indonesia untuk memberantas penyalahgunaan narkoba ini telah menempuh berbagai bentuk kebijakan, baik kebijakan penal maupun kebijakan non penal. Kebijakan hukum pidana (kebijakan penal) mulai dari pemerintah melalui badan legislatif telah terulang kali mengeluarkan dan merevisi aturan yang ada di bidang narkotika dan psikotropika. Sejak tahun 1976 dengan Undang-Undang No. 9 Tahun 1976 tentang Narkotika, berlanjut diadakan revisi atau perubahan UU No. 5 Tahun 1997 tentang Psikotropika. Karena UU sebelumnya dipandang masih gagal dalam memberantas narkotika, maka UU tersebut direvisi dan dirubah lagi terakhir dengan UU No. 35 Tahun 2009 tentang Narkotika.

Kebijakan non penal berupa dalam usaha pemberantasan Narkotika pemerintah membentuk lembaga khusus ditingkat pusat sampai ke daerah Provinsi, Kabupaten dan Kota. Lembaga tersebut adalah Badan Narkotik Nasional (BNN), dengan dasar hukum pembentukannya : Peraturan Presiden RI Nomor 23 Tahun 2010 yang ditetapkan tanggal 12 April 2010. Indonesia juga telah meratifikasi Konvensi PBB tentang Pemberantasan Peredaran Gelap Narkotika dan Psikotropika(United Nations Convention Against Ellicit Traffic in Narcotic Drugs and Psychotorpic Substance). Dengan Indonesia telah meratifikasi konvensi PBB tersebut maka berarti negara kita telah memiliki komitment dengan negara-negara lain di dunia untuk sepakat memerangi bahaya narkotika serta memberantasnya sebagai bentuk solidaritas bangsa-bangsa untuk menyelematkan anak bangsa di muka bumi ini.

Dengan semakin sering dan maraknya pengendalian peredaran gelap narkotika oleh narapidana dari balik jeruji besi atau dari dalam LAPAS hampir di seluruh LAPAS yang ada di Indonesia, dan pula melibatkan bukan saja narapidana, bahkan di fasilitasi oleh petugas LAPAS, secara analis teoritik menenunjukkan adanya kegagalan sebuah "sistem" yang ada, dalam hal ini terjadi dis order di bidang penegakan dunia peradilan. Sistem peradilan pidana Indonesia terpadu (Integrated Crminal Justice System) tampak kecenderungan sebagai "Criminal Justice System is not a True System". Dengan tampak fenomena, gejala, fakta penegakan hukum, di bidang pemberantasan narkotika seperti terurai diatas, maka peneliti tertarik melakukan penelitian dengan judul "Pengendalian Peredaran Gelap Narkotika Oleh Narapidana Dari Dalam Lembaga Pemasyarakatan (LAPAS)". 


\subsection{Permasalahan}

Dari paparan latar belakang diatas, maka disajikan rumusan permasalahan seperti berikut :

1. Bagaimana korelasi pengaturan perundang-undangan pidana Indonesia mengenai koordinasi diantara penyidik tindakpidananarkotikadenganpenegak hukum lainnya dalam melakukan fungsinya untuk memberantas peredaran gelap narkotika?

2. Kenapa sering terjadi pengendalian peredaran gelap narkotika dilakukan oleh narapidana dari dalam Lembaga Pemasyarakatan?

\section{Metode Penelitian}

\subsection{Jenis penelitian}

Penelitian ini merupakan penelitian hukum normatif atau lingkup ilmu hukum dogmatik yang memiliki karakter "suigeneris" yang ditandai

dengan ciri-ciri bahwa ; ilmu hukum yang memberikan suatu, serta memiliki suatu sifat empiris-analistis suatu pemaparan dan analisis tentang isi (struktur) dari hukum yang berlaku bersifat menginterprestasikan hukum yang berlaku : melakukan penelitian terhadap hukum yang berlaku, memberikan model teoritis terhadap praktek hukum

\subsection{Metode Pendekatan}

Pendekatan terhadap permasalahan dalam penelitian ini akan dilakukan dengan 3 (tiga) pendekatan yaitu pendekatan analisis konsep hukum (analytical and conceptual approach), pendekatan perundang-undangan (statues analytical approach) dan pendekatan kasus (cases approach)

\subsection{Sumber Bahan Hukum}

Di dalam jenis penelitian hukum yang bersifat normatif kualiflkasi bahan hukum yang lazim digunakan adalah :

a. Bahan Hukum Primer

1) Norma Dasar Pancasila

2) Undang-Undang Dasar Negara RI Tahun 1945

3) Peraturan Perundang-Undangan

b. Bahan Hukum Sekunder

1) Rancangan Peraturan Perundangundangan

2) Hasil Karya Ilmiah para pakar hukum

c. Bahan Hukum Tersier

Yaitu bahan hukum yang memberikan informasi tentang bahan hukum primer dan sekunder meliputi biografi ${ }^{3}$.

Dalam penelitian ini, sumber bahan hukum yang dipergunakan bersumber dari 2 (dua) sumber bahan hukum, yaitu : 1) sumber bahan hukum primer ; dan sumber bahan hukum sekunder,

1) Bahan hukum primer diperoleh dari sumber yang meningkat (authoritative source), dalam bentuk peraruran perundang-undangan yang tcrkait dcngan kewenangan penegak hukum dalampencegahan dan penanggulangan tindak pidana Narkotika seperti :

a) Undang-Undang Dasar Negara Republik Indonesia Tahun 1945

b) Undang-Undang Nomor 8 Tahun 1981 tentang Hukum Acara Pidana.

c) Undang-Undang Nomor 35 Tahun 2009 tentang Narkotika.

Rony Hamijoyo Soemantri, 1988, Metode Penelitian Hukum dan Jurimetri, Ghalia Indonesia, Jakarta, hlm.11 dan 12. 
2) Sumber bahan hukum sekunder diperoleh dari hasil-hasil penelitian kepustakaanataubuku-buku (literatur), jurnal, karya tulis dalam bentuk artikel sepanjang menyangkut kewenangan penegak hukum dalam pencegahan dan penanggulangan serta pemberantasan tindak pidana Narkotika.

\subsection{Metode Pengumpulan Bahan Hukum}

Dalam metode pengumpulan bahan hukum dalam penelitian hukum normatif, yaitu metode bola salju dan metode sistematis, maka kedua metode tersebut juga dipergunakan dalam penelitian ini. Metode bola salju dimaksud dilakukan dengan cara penelusuran bahan acuan yang dipergunakan dalam buku-buku ataupun hasil penelitian yang berkaitan erat dengan masalah yang diteliti dalam penelitian ini. Secangkan metode sistematis dimaksud, adalah dengan mempergunakan sarana bantu berupa catatan kecil untuk mempermudah penelusuran bahan hukum yangdipcrlukan dalam penelitian ini. Sumber bahan hukum sekunder ini bermanfaat sebagai :

a. Sebagai sumber materiil

b. Untuk meningkatkan mutu interpretasi atas hukum positif yang berlaku dan

c. Untuk mengembangkan hukum sebagai nsuatu sistem normatif yang komprehensif dan tuntas, baik dalam maknanya yang formal maupun dalam makna yang materiil ${ }^{4}$.

Burhan Ashofa, 2001, Metode Penelitian Hukum. PT. Rineka Cipta, Jakarta, hlm.42.

\subsection{Analisis Bahan Hukum}

Dalam menganalisa penelitian hukum normatif yang dianalisis bukanlah data, tetapi bahan hukum yang diperoleh melalui penelusuran dengan metode tersebut diatas. Dimana bahan hukum yang berhasil dikumpulkanakan dilakukansecaradeskriptif - analitis evaluatif. Jadi dalam hal ini akan digambarkan secara utuh dalam artian uraian apa adanya terhadap suatu kondisi atau posisi hukum. Kemudian tehnik ini dilanjutkan dengan langkah analisis. Analisis yang dikemukakan bersifat evaluatif, dalam arti melakukan evaluasi atau penilaian terhadap norma hukum dalam peraturan perundangundangan terkait tentang narkotika dalam pencegahan dan penanggulangan tindak pidana Narkotika beserta peraturan lain yang mendukungnya. Disamping mengevaluasi, juga melakukan interpretasi dalam arti menafsirkan norma yang memuat tentang kewenangan LAPAS dalam pencegahan dan penanggulangan tindak pidana Narkotika. Tehnik interpretasi yang digunakan antara lain : interpretasi gramatical, interpretasi sistimatis dan interpretasi kontektual.

Pendekatan kasus berarti mengacu pada kasus tindak pidana narkotika yang telah memiliki kekuatan hukum tetap (inkracht van gewijsde) dan terpidananya telah dieksekusi dan ditempatkan di dalam Lembaga Pemasyarakatan (LAPAS).

\section{Hasil dan Pembahasan}

31. Data Penanganan Kasus Peredaran Gelap Narkotika di Kalangan Narapidana

Peredaran gelap narkotika di

Bali telah masuk ke dalam tahap yang mengkhawatirkan, karena konsumen 
narkotika di Bali khususnya di kota-kota besar masih terbilang tinggi, sehingga banyak para pengedar atau bandar narkotika yang berkeliaran untuk membisniskan narkotika dengan harga yang sangat mahal. Demi kelancaran bisnis narkotika tersebut, para bandar atau pengedar narkotika memperluas jaringan dan mengembangkan pola serta menjaring orang-orang baru dari berbagai kalangan dan usia. Semakin canggihnya modus-modus sindikat peredaran gelap narkotika menyebabkan semakin tingginya tingkat kerawanan peredaran gelap narkotika di Bali, karena saat ini peredaran gelap narkotika sudah menjangkau seluruh lapisan masyarakat, bahkan jalur peredaran gelap yang digunakan pun telah sampai pada titik-titik pelabuhan-pelabuhan tidak resmi atau pelabuhan-pelabuhan tradisional yang notabene tidak dapat dijangkau seluruhnya oleh petugas.

Kasubsi Pelaporan dan Tata Tertib Lapas Kelas II A Denpasar (Ibu Sarjiyem) mengemukakan bahwa, maraknya penyalahgunaan dan peredaran gelap narkotika di Bali dimulai sejak tahun 1980an, dimana awalnya para pelaku berasal dari orang asing (WNA) yang pada saat itu datang berkunjung ke Bali. Seiring berjalannya waktu, kasus-kasus narkotika semakin berkembang di masyarakat dan mencapai puncaknya pada awal tahun 2000. Mulai saat itulah narapidana kasus narkotika semakin meningkat tiap tahunnya ${ }^{5}$. Meningkatnya peredaran gelap narkotika di Bali dibuktikan dengan munculnya fakta bahwa, Bali saat ini sudah tidak lagi menjadi tern pat transit

Wawancara dengan Kasubsi Pelaporan dan Tata Tertib Lapas Kelas II A Denpasar (Ibu Sarjiyem, SE), pada tanggal 21 Januari 2015, pukul 11.00 WITA, bertempat di Lapas Kelas II A Denpasar. peredaran gelap narkotika, akan tetapi sudah menjadi pasar potensial bagi perdagangan gelap narkotika oleh para sindikat narkotika internasional Bali dianggap sebagai daerah strategis dan cukup dikenal di dunia sebagai salah satu destinasi wisata terbaik di dunia, sehingga beberapa anggota sindikat narkotika internasional ada yang tinggal di Bali. Oleh karena MIL tidak mudah untuk mengungkap jaringan peredaran gelap narkotika ${ }^{6}$.

Kasat Reserse Narkoba Polres Badung (Bapak Bambang I Gede Artha) dalam wawancaranya menyebutkan bahwa, tidak mudah untuk mengungkap jaringan peredaran gelap narkotika di Bali disamping manajemen dan pendanaannya yang sangat bagus, peredaran gelapnya juga melibatkan anggota sindikat narkotika internasional hingga melakukan kejahatan pencucian uang dari hasil bisnis peredaran gelap narkotika tersebut. ${ }^{7}$ Hasil yang diperoleh dari perdagangan gelap narkotika dapat mencapai angka miliaran hingga triliunan rupiah, karena harga narkotika per gramnya dapat mencapai Rp. 3.000.000,00 (tiga juta rupiah), sehingga bisnis tersebut tentu akan menarik minat banyak orang, mengingat semakin meningkatnya jumlah permintaan (demand) akan narkotika oleh para pengguna atau pengkonsumsi narkotika di Bali. Tingginya jumlah konsumsi narkotika di Bali menyebabkan para pengedar atau bandar

\footnotetext{
Maiwa News, 2012, Bali Pasar Potensial Sindikat Narkoba Internasional, Serial Online 2 Juli 2012, tersedia di website http://berita.maiwanews.com/balipasar-potensial-sindikat-narkoba internasional-27083. $\mathrm{html}$, diakses pada tanggal 4 Januari 2015.

Wawancara dengan Kasat Reserse Narkoba Polres Badung (Bambang I Gede Artha), tanggal 9 Febmari 2015, pukul 11.30 WIT A, bertempat di ruang Reserse Narkoba Polres Badung.
} 
narkotika akan menggunakan berbagai cara untuk dapat menyelundupkan narkotika, baik melalui jalur transportasi darat, laut, dan udara, seperti penyelundupan melalui bandar udara, kapal laut, pengiriman via pos, via titipan kilat, dan lain-lain.

Selanjutnya Kasat Narkoba Polres Badung (Bapak Bambang I Gede Artha) mengemukakan bahwa ada beberapa faktor penyebab meningkatnya peredaran gelap narkotika di Bali yaitu :

a. Kemajuan IPTEK, dimana semakin canggihnya perkembangan teknologi khususnya pada alat-alat komunikasi seperti handphone, menyebabkan handphone sering disalahgunakan sebagai sarana utama para sindikat narkotika dalam melancarkan peredaran gelap narkotika. Semakin canggih perkembangan teknologi maka semakin mudah juga para sindikat narkotika saling berkomunikasi satu sama lain hingga melampaui batas negara.

b. Bali merupakan daerah pariwisata, sehingga Bali banyak dikunjungi oleh wisatawan baik wisatawan lokal maupun mancanegara. Tidak sedikit kedatangan wisatawan ke Bali yang terlibat dalam kasus peredaran gelap narkotika, dimana salah satunya dibuktikan dengan adanya wisawatan yang ketika datang berlibur di Bali, tertangkap oleh petugas membawa narkotika atau obat-obat berbahaya lainnya.

c. Banyaknya akses masuk ke Bali yang tidak semuanya bisa dipantau oleh petugas, khususnya jalur laut seperti pelabuhan-pelabuhan tradisional yang tersebar hampir di seluruh wilayah
Bali. Pelabuhan-pelabuhan tradisional digunakan sebagaijalurpenyelundupan narkotika karena tidak semua titik-titik pelabuhan tradisional di Bali berada di bawah pengawasan dan pengamanan petugas. Hal tersebut diakibatkan karena kurangnya personel petugas untuk melakukan pengamanan di titiktitik tersebut dan kurangnya partisipasi masyarakat dalam hal pelaporan atau pengaduan kepada pihak yang berwajib terhadap kegiatan yang menyangkut peredaran gelap narkotika.

d. Kesadaran hukum masyarakat Bali akan bahaya penyalahgunaan dan peredaran gelap narkotika masih kurang.Terkadangadamasyarakatyang sadar dan tahu bahwa penyalahgunaan dan peredaran narkotika dilarang oleh UU, namun tetap tidak taat atau tidak patuh. Di samping itu, masih adanya sifat acuh tak acuh masyarakat terhadap adanya dugaan tindak pidana narkotika di sekitarnya, menyebabkan mudahnya narkotika diselundupkan ke Bali.

e. Tingginya angka pengguna narkotika di Bali yang menyebabkan permintaan akan jumlah narkotika juga semakin meningkat. Oleh karena itu, peredaran gelap narkotika semakin sulit untuk diberantas, sehingga membutuhkan peran serta masyarakat khususnya dalam hal pelaporan terjadinya penyalahgunaan dan peredaran gelap narkotika ${ }^{8}$.

Wawancara dengan Kasat Reserse Narkoba Polres Badung ( AKP Bambang I Gede Artha), tanggal 9 Februari 2015, pukul 11.30 WIT A, bertempat di ruang Reserse Narkoba Polres Badung, 
Upaya penegakan hukum yang dilakukan oleh Polres Badung dalam rangka memberantas peredaran gelap narkotika meliputi, pengungkapan dan penyelesaian kasus (sampai di tahap penyidikan) baik yang dilakukan oleh Warga Negara Indonesia (WNI) maupun terhadap pelaku yang berkewarganegaraan asing (WNA). Adapun data pengungkapan dan penyelesaian kasus yang dilakukan oleh Satuan Reserse Narkoba Polres Badung dalam kurun waktu lima tahun terakhir (2010 - 2014) dapat dilihat dalam tabel berikut ini:

\section{Tabel Data Pengungkapan dan Penyelesaian Kasus Narkoba di Polres Badung Periode 2010 - 2014}

\begin{tabular}{|c|l|c|c|c|c|c|}
\hline \multirow{2}{*}{ No } & \multirow{2}{*}{$\begin{array}{c}\text { Tindakan } \\
\text { Hukum }\end{array}$} & \multicolumn{5}{|c|}{ Jumlah Kasus Tindak Pidana Narkoba } \\
\cline { 3 - 7 } & & 2010 & 2011 & 2012 & 2013 & 2014 \\
\hline 1 & $\begin{array}{l}\text { Pengungkapan } \\
\text { Kasus }\end{array}$ & 68 & 45 & 42 & 44 & 15 \\
\hline 2 & Penyelesaian & 60 & 45 & 23 & 32 & 14 \\
\hline
\end{tabular}

Sumber : Dit Reserse Narkoba Polda Bali

Berdasarkandatadiatasdapatdijelaskan bahwa, jumlah pengungkapan kasus narkoba oleh Reserse Narkoba Polres Badung selama kurun waktu lima tahun terakhir adalah 214 kasus. Dari jumlah pengungkapan kasus tersebut, Reserse Narkoba Polres Badung berhasil menyelesaikan kasus narkoba sebanyak 174 kasus yaitu, 60 kasus (tahun 2010), 45 kasus (tahun 2011), 23 kasus (tahun 2012), 32 kasus (tahun 2013), dan 14 kasus (tahun 2014). Jumlah pengungkapan kasus pada masing-masing tahun berbeda dengan jumlah penyelesaian kasus, dimana jumlah penyelesaian kasus ada yang lebih sedikit dibandingkan dengan jumlah pengungkapan kasus. Kondisi tersebut disebabkan karena tidak cukupnya barang bukti dan meninggalnya tersangka, sehingga penyelidikan harus dihentikan.

\subsection{Modus Pelaku Peredaran Gelap Narkotika di Kalangan Narapidana}

Mencermati data tentang kasus peredaran gelap narkotika di kalangan narapidana yang telah dipaparkan pada sub bab sebelumnya, bahwasannya ada beberapa faktor penyebab keterlibatan narapidana dalam peredaran gelap narkotika, baik faktor internal maupun eksternal. Faktor internal berkaitan dengan masalah sarana dan prasarana serta pengawasan dan kontrol petugas di daiam Lapas itu sendiri, sedangkan faktor eksternal yang dihadapi berkaitan dengan kecenderungan yang sangat tinggi dijatuhkannya sanksi penjara/pengurungan atas pelanggaran hukum sehingga akibat dominasi penjatuhan pidana penjara tersebut, Lapas menjadi overcapacity. Sudirman dalam A. Josias Simon mengemukakan bahwa "makin besar jumlah narapidana terisi penuh sesak dalam Lapas, berperan meninskatkan pelanggaran-pelanggaran aturan dan penyimpangan terhukum. ${ }^{9}$ Hampir seluruh Lapas dan Rutan di Bali kelebihan daya tampung (over capacity), sehingga perlu segera diatasi seperti yang

Didin Sudirman, 2007, Reposisi dan Revitalisasi Pemasyarakatan Dalam Sistim Peradilan Pidana di Indonesia, Pusat Pengkajian dan Pengembangan Kebijakan (Pusjianbang) Departemen Hukum dan Hak Asasi Manusia Republik Indonesia, h. 205-230, dikutip dari A. Josias Simon R, 2012, Budaya Penjara: Pemahaman dan Implementasi, Karya Putra Darwati, Bandung, hlm.11. 
dialami oleh Lapas Kelas II A Denpasar, Lapas Kelas II B Tabanan, Lapas Kelas II B Singaraja, Rutan Kelas II B Negara, Rutan Kelas II B Gianyar, dan Rutan Kelas II B Klungkung. ${ }^{10}$

Berdasarkan data yang peneliti peroleh dari Divisi Pemasyarakatan Kemenkumham Kanwil Bali, bahwa pada periode Januari 2015 jumlah tahanan dan narapidana kasus narkotika tertinggi berada di Lapas Kelas II A Denpasar di Kerobokan dengan jumlah 439 orang, kemudian disusul oleh Rutan Kelas II B Bangli dengan jumlah 52 orang, Lapas Kelas II B Karangasem dengan jumlah 45 orang, Lapas Kelas II B Singaraja dengan jumlah 44 orang, Lapas Kelas II B Tabanan dengan jumlah 42 orang, Rutan Kelas II B Klungkung dengan jumlah 34 orang, Rutan Kelas II B Gianyar dengan jumlah 13 orang, Rutan Kelas II B Negara dengan jumlah 9 orang, dan Lapas Anak Kelas II B Gianyar di Karangasem dengan jumlah 6 orang. Tidak ada pemisahan blok bagi narapidana kasus tindak pidana narkotika dengan narapidana kasus lainnya mengingat sebagian be\$ar Lapas dan Rutan di Bali mengalami overcapacity. Di samping itu, belum difungsikannya Lapas khusus narkotika di Bangli hingga saat ini, juga menjadi faktor tidak adanya pengkhususan blok human bagi narapidana narkotika. Upaya untuk segera mengoperasikan Lapas khusus bagi narapidana narkotika di Bali masih terus dilakukan oleh Pemerintah, karena kondisi Lapas yang demikian justru akan sering memicu terjadinya berbagai keributan atau

10 Sistem Database Pemasyarakatan, 2014, Data Terahhir Jumlah Penghuni per-UPT Pada Kanwil Bali Periode Desember 2014, tersedia di website http://smslap. ditjenpas.go.id, diakses pada tanggal 8 Januari 2015. kerusuhan antar narapidana. Di samping itu, akibat dari kelebihan kapasitas isi/hunian yang menyebabkan tidak adanya pemisahan antara blok pengedar dan pengguna dengan blok yang lainnya (tindak pidana umum), cenderung menjadi pemicu utama terjadinya kasus penyalahgunaan dan peredaran gelap narkotika. ${ }^{11}$

David J. Cooke mengemukakan bahwa "narapidana tidak hanya mengalami tekanan di Lapas sebab mereka juga mungkin mempunyai masalah di luar. ${ }^{12}$ Dampak psikologis ketika narapidana berada di Lapas juga menjadi faktor pemicu terlibatnya narapidana dalam kasus peredaran gelap narkotika. Narapidana yang berada dalam situasi demikian, akan berusaha mencari ketenangan melalui narkotika karena efek penggunaan narkotika dianggap mampu memberikan ketenangan dan menjauhkan seseorang dari berbagai macam masalah dan bagi narapidana yang sedang berada dalam kesulitan ekonomi di Lapas akan berusaha mencari celah untuk melakukan peredaran gelap narkotika, sehingga ia mampu memenuhi kebutuhan hidupnya dan keluarganya selama berada di Lapas karena seperti yang telah diuraikan sebelumnya bahwa penghasilan dari bisnis peredaran gelap narkotika dapat mencapai angka miliaran hingga triliunan rupiah.

Faktor internal lain penyebab terjadinya peredaran gelap narkotika di kalangan narapidana juga disebabkan oleh kurangnya

Achmad Rifai, 2014, Narkoba di Balik Tembok Penjara, Aswaja Pressindo, Yogyakarta, hlm. 17.

12 David J. Cooke, dkk, 2008, Menyingkap Duma Gelap Penjara, PT. Gramedia Pustaka Utama, Jakarta, hlm.85. 
pengawasan dan kontrol oleh petugas Lapas itu sendiri. Masih ditemukannya penggunaan alat telekomunikasi (handphone) di kalangan narapidana akan mempermudah narapidana berkomunikasi dengan orang-orang di luar Lapas (kurir narkotika), sehingga secara langsung akan memperlancar peredaran gelap narkotika. Keterlibatan oknum petugas Lapas juga menjadi pemicu peredaran gelap narkotika di kalangan narapidana, seperti kasus yang terjadi pada awal bulan Januari 2015, dimana seorang oknum sipir Lapas Kelas II A Denpasar berinisial JES ditangkap oleh satuan Reserse Narkoba Polresta Denpasar yang diduga menjual narkotika di dalam Lapas. Penangkapan tersebut didasarkan atas laporan dari tersangka WBA pada hari yang sama memberikan informasi bahwa JES sering mengedarkan narkotika di sekitar Lapas Kelas II A Denpasar.

Faktor eksternal penyebab terjadinya kasus peredaran gelap narkotika di kalangan narapidana disebabkan karena masih banyak pengguna narkotika yang dijatuhi pidana penjara, sehingga narapidana yang sudah berada dalam keadaan ketergantungan sewaktu-wakru akan membutuhkan narkotika. Hal inilah yang akan menjadi pemicu maraknya penyelundupan narkotika ke dalam Lapas hinggaterjadi peredaran gelap narkotika. Berkenaan dengan hal tersebut, salah seorang mantan narapidana narkotika yang pernah menjalani pidana di Lapas Kelas II A Denpasar (inisial IGACP) dan saat ini menjalani rehabilitasi, mengemukakan bahwa seorang pengguna atau pecandu narkotika yang dijatuhi pidana penjara, tidak akan mampu mengembalikan kondisi pengguna narkotika kembali normal, karena rehabilitasi pun tidak bisa $100 \%$ memulihkan keadaan seorang pengguna narkotika untuk tidak ketergantungan atau menggunakan narkotika lagi. ${ }^{13}$ Beliau sendiri sudah menggunakan banyak jenis zat narkotika (seperti heroin, sabu, ganja, dan inex) sejak duduk di bangku Sekolah Menengah Atas (SMA) hingga tahun 2014 dan pernah dua kali menjalani pidana penjara di Lapas Kelas II A Denpasar, namun beliau masih tetap ketergantungan terhadap narkotika. Oleh karena itu, beliau menganggap penjatuhan pidana penjara terhadap pengguna narkotika adalah kurang tepat. Hal serupa diungkapkan oleh salah satu petugas BNN Provinsi Bali di bagian deputi pemberantasan dalam wawancara tidak terstruktur yang peneliti lakukan, dimana beliau menghimbau agar para pengguna narkotika khususnya para pecandu tidak dijatuhi pidana penjara, akan tetapi lebih diarahkan untuk mengikuti program rehabilitasi, baik itu rehabilitasi medis maupun rehabilitasi sosial.

Hasil penelitian ini menunjukkan bahwa tidak mudah untuk melakukan penegakan hukum terhadap pelaku peredaran gelap narkotika di kalangan narapidana, sehingga ketidakmudahan tersebut berujung pada belum maksimalnya penegakan hukum yang dilakukan oleh Polres Badung terhadap pelaku peredaran gelap narkotika di kalangan narapidana. Keterbatasan ruang gerak aparat penegak hukum khususnya Kepolisian yang disebabkan karena dalam pelaksanaannya Polisi harus berhadapan dengan kode etik profesi lembaga lain (Lapas), faktor keamanan dan keselamatan serta status

\footnotetext{
3 Wawancara dengan Mantan Pengguna Narkotika Sekaligus Pasien Rehabilitasi di BNN Kota Denpasar (inisial IGACP), tanggal 7 Januari 2015, pukul 09.00 WIT A, bertempat di BNN Kota Denpasar.
} 
narapidana yang merupakan warga binaan Lapas, secara langsung telah menyebabkan tidak maksimalnya pelaksanaan penegakan hukum, baik dalam hal penyelidikan maupun penyidikan. Sama halnya dengan Lapas yang merupakan bagian tidak terpisahkan dari rangkaian proses penegakan hukum dalam sistem peradilan pidana, belum mampu secara maksimal menjalankan fungsi pembinaannya kepada warga binaan pemasyarakatan karena terbukti masih banyak narapidana yang terlibat dalam penyalahgunaan dan peredaran gelap narkotika.

Belum maksimalnyapenegakan hukum terhadap pelaku peredaran gelap narkotika di kalangannarapidanamenunjukkanpenurunan kemampuan hukum dalam menanggulangi kejahatan sebagaimana dikemukakan oleh Arbi Samit bahwa, penurunan kemampuan hukum untuk menanggulangi kejahatan terjadi karena struktur hukum dengan fungsi hukum tidak berkembang secara paralel sehingga penegakan hukum cenderung melemah. ${ }^{14}$ Terhadap persoalan-persoalan yang selama ini menjadi penyebab tidak mudahnya pelaksanaan penegakan hukum oleh Kepolisian khususnya dalam hal penyelidikan dan penyidikan secara langsung akan berpengaruh pada efektivitas hukum karena merujuk pada teori efektivitas hukum yang diungkapkan oleh Paul dan Dias yang kemudian disempurnakan kembali oleh konsep efektivitas hukum oleh Derita Prapti Rahayu bahwa, agar suatu hukum itu efektif dan dapat mencapai sasarannya maka beberapa elemen dasar dalamhukumharuslah

14 Heri Tahir, 2010, Proses Hukum yang Adil Dalam Sistem Peradilan Pidana di Indonesia, Laksbang, Yogyakarta, hlm.97. berjalan atau berfungsi dengan baik. Apabila salah satu elemen dasar hukum tersebut tidak berfungsi dengan baik maka otomatis hukum tidak dapat berlaku secara efektif. Penegakan hukum yang sungguh-sungguh, tidak memihak, dan fair sebagai salah satu elemen dasar yang dibutuhkan dalam rangka mengefektifkan hukum semestinya tetap digunakan sebagai dasar oleh Kepolisian dalam menanggulangi peredaran gelap narkotika di kalangan narapidana. Bagaimanapun kondisinya, penegakan hukum haruslah tetap dilaksanakan apalagi jika pelakunya adalah seorang narapidana yang semestinya menjalani pembinaan namun justru terlibat dalam peredaran gelap narkotika. Begitu juga dengan Lapas, dimana untuk menanggulangi penyalahgunaan dan peredaran gelap narkotika di kalangan narapidana, Lapas dapat berpartisipasi aktif dalam hal pelaporan tentang adanya dugaan narapidana yang terlibat mengingat adanya keterbatasan ruang gerak yang dimiliki oleh Polisi dalam melaksanakan penegakan hukumnya baik dalam hal penyelidikan maupun penyidikan, atau tindakan hukum lain yang berkaitan dengan penyelidikan dan penyidikan.

Mengacu pada apa yang telah dikemukakan oleh Joseph Goldstein dalam teori penegakan hukum pidana, dimana beliau membagi penegakan hukum pidana menjadi tiga bagian, yaitu total enforcement ..full enforcement, dan actual enforcement. Dalam teorinya beliau membenarkan adanya keterbatasan-keterbatasan dalam penegakan hukum pidana yang disebabkan oleh beberapa faktor seperti hukum pidana substantif, hukum acara pidana (aturan-aturan penangkapan, penahanan, penggeledahan, 
penyitaan, dan pemeriksaan pendahuluan), keterbatasan dalam bentuk waktu, personil, alat-alat investigasi, dana dan sebagainya. Seluruhketerbatasan tersebutsecaralangsung akan membatasi ruang gerak aparat penegak hukum dalam pelaksanaan penegakan hukum pidana. Jika dikaitkan dengan permasalahan penegakan hukum oleh Polres Badung terhadap pelaku peredaran gelap narkotika di kalangan narapidana selama ini, maka teori Joseph Goldstein relevan untuk menjawab persoalan mengenai keterbatasan ruang gerak yang dialami oleh Polres Badung ketika dihadapkan dengan kode etik profesi lembaga lain (Lapas), posisi narapidana di dalam Lapas, status narapidana sebagai warga binaan, kondisi dan keamanan di lingkungan narapidana, serta ketentuan penegakan hukum (khususnya penyidikan) yang harus diperhatikan dalam Pasal 17 UU RI No. 12 Tahun 1995 Tentang Pemasyarakatan, di samping keterbatasan dalam bentuk anggaran dan sarana pendukung. Untuk memaksimalkan penegakan hukum terhadap pelaku peredaran gelap narkotika di kalangan narapidana maka koordinasi dan kerjasama antara Kepolisian dengan pihak Lapas memang sangat dibutuhkan karena bagi peneliti sendiri peran Lapas justru lebih besar dalam mengungkap peredaran gelap narkotika yang dilakukan oleh narapidana di dalam Lapas. Dalam hal ini, peneliti cenderung melihat peran Polisi lebih besar ketika mengungkap jaringan peredaran gelap narkotika yang dikendalikan oleh narapidana dari dalam Lapas yang tentunya diperoleh dari hasil pemeriksaan yang mendalam terhadap kurir-kurir narkotika yang tertangkap.
Terlepas dari persoalan besar kecilnya peran penegak hukum dalam mengungkap peredaran gelap narkotika di kalangan narapidana, hal yang penting untuk dikedepankan adalah bagaimana mencegah agarnarapidanatidak terlibat dalam peredaran gelap narkotika dan bagaimana mencegah keberadaan narkotika di dalam Lapas. Penegakan hukum terhadap narapidana yang melakukan peredaran gelap narkotika sebenarnya mengandung unsur pencegahaii, karena dengan dilakukan penegakan hukum terhadap para pelaku yang terlibat dengan sanksi yang tegas akan memberikan efek jera dan rasa takut bagi calon-calon pelaku narapidana yang lain. Akan tetapi, penegakan hukum terhadap narapidana tidak saja cukup untuk menekan atau menghentikan peredaran gelap narkotika di kalangan narapidana, dimana penegakan hukum terhadap oknumoknum aparat yang terlibat atau membantu kelancaran peredaran gelap narkotika harus ditindak dengan tegas sesuai dengan asas equality before the law. Di samping itu pula, upaya penegakan hukum harus juga didukung dengan upaya preventif lainnya pemisahan blok antara narapidana pengedar dengan pengguna narkoba, dan pengetatan hak-hak narapidana. Pengetatan terhadap hak-hak narapidana perlu dilakukan karena terbukti masih ada beberapa pengunjung yang bermufakat dengan narapidana untuk memasukkan narkotika ke dala LAPAS, serta adanya fakta dimana narapidana yang setelah diberikan pembebasan bersyarat ternyata melakukan peredaran gelap narkotika di luar LAPAS. Oleh karena itu, segala jenis upaya penanggulangan terhadap peredaran gelap narkotika di kalangan narapidana harus terus dioptimalkan demi 
mengefektifkan tujuan pembinaan serta memberantas penyalahgunaan dan peradan gelap narkotika di kalangan narapidana.

\section{Simpulan dan Saran}

\subsection{Simpulan}

Adapun sebagai simpulan dalam penelitian sebagai hasilakhir atas penelusuran dan kajian atau analitis peredaran gelap narkotika yang dilakukan oleh narapidana dari dalam Lembaga Pemasyarakatan (LAPAS) dengan mengambil obyek penelitian memakai sampel data penunjang sebagai bahan hukum di LAPAS Klas IIA Kerobokan Denpasar, dapat disimpulkan 2 (dua hal seperti berikut :

4.1.1 Bahwa Ternyata secara yuridis normatif teoritikal belum terdapat atau menunjukkan adanya pengaturan secarasubstansialperaturanperundangundangan yang mengatur tentang korelasi dan koordinasi antara undangundang terkait seperti KUHAP (UU No. 8 Tahun 1981) dengan Undang - Undang Nomor 12 Tahun 1995 tentang Pemasyarakatan khususnya dalam hal penyidik untuk melakukan penyidikan di dalam LAPAS. Sehingga secara teknis penyidik akan melakukan penyidikan ke dalam LAPAS seperti penggeledahan, penangkapan mengalami kesulitan. Karena secara yuridis formal wilayah atau areal LAPAS sebagai tempat (locus delicty) apabila narapidana diduga melakukan peredaran narkotika atau sebagai pengendali peredaran gelap dari dalam LAPAS ke luar LAPAS atau melakukan di dalam LAPAS sulit bagi penyidik melakukan tindakan hukum sesuai kewenangannya. Tampak bahwa aktivitas atau pengendalian peredaran gelap narkotika dengan para pelakunya masih berstatus narapidana atau warga binaan pemasyarakatan dengan modus operandi dilakukan dari dalam dan atau keluar LAPAS masih sulit dilakukan karena berbagai faktor internal dan eksternal LAPAS.

4.1.2 Seringnya masih terjadi pengendalian peredaran gelap narkotika dengan pelakunya melibatkan narapidana dari dalam dan keluar LAPAS diakibatkan oleh beberapa sebab seperti :

1) Terbatasnya kuantitas pegawai LAPAS, dalam aktivitas pengawasannya menjadi sangat terbatas, karena ratio jumlah pegawai LAPAS (Sipir) dengan narapidana yang diawasinya tidak seimbang, bahkan jauh melebihi jangkauan ratio normal, karena LAPAS penghuni narapidananya sudah oper kapasitas (overload) / oper capacity.

2) Masih sering kedapatan narapidana membawa dan memakai alat komunikasi seperti handhpone untuk dipakai berkomunikasi keluar LAPAS, sehingga mudah melakukan kontak personal dengan dunia luar untuk dimanfaatkan membina dan melakukan jaringan bisnis narkotika.

3) Longgarnya pengaturan tentang kunjungan pihak luar seperti kerabat dan keluarga narapidana untuk masuk ke dalam LAPAS, sebagai peluang pihak tertentu yang masih berada di dalam LAPAS 
sebagai pengendali jaringan narkotika untuk dunia luar tembok LAPAS yang seolah-olah bahwa di dalam LAPAS aman untuk itu, atau terkesan LAPAS steril dari aktivitas peredaran narkotika.

4) Masih ada beberapa oknum internal pegawai LAPAS yang bekerjasama dengan narapidana melakukan bisnis haram narkotika tersebut karena tergiur dengan hasil yang menggiurkan dengan keuangan mendapat uang secara mudah dan dalam jumlah banyak, dibanding penghasilan gaji mereka yang diperolehnya

5) Masih tampak adanya kelemahan dalam upaya pemberantasan tindak pidana narkotika, disatu sisi ada pengaturan penjatuhan sanksi berat badi pengedar narkotika, di lain pihak bagi pemakai dikenakan sanksi yang demikian lemah, bahkan direhabilitasi, padahal pemakai sebelumnya tidak tertutup kemungkinan sebelumnya mereka sebagai pengedar.

\subsection{Saran}

4.2.1 Agar pengawasan bagi narapidana oleh pihakLAPASlebihditingkatkandengan tidak membolehkan berkomunikasi dengan pihak luar LAPAS serta meniadakan atau melarang keras ada fasilitas alat komunikasi dibawa dan dipakai dalam LAPAS oleh narapidana, kalau kedapatan pemakaian alat komunikasi teknologi informasi diberi sanksi berat.

4.2.2 Agar kementrian Departemen Hukum dan HAM memberi sanksi berat bagi pegawai LAPAS yang terbukti turut serta memfasilitasi narapidana untuk melakukan aktivitas peredaran gelap narkotika di dalam dan / atau keluar LAPAS, terlebih lagi bila menjalin jaringan sampai ke luar negeri.

\section{DAFTAR PUSTAKA}

Burhan Asofa, 2001, Metode Penelitian Hukum, Rineka Cipta, Jakarta

Chawawi, Adami, 2011, Pelajaran Hukum Pidana, Bagian 1, Rajawali Pers. Jakarta.

Departemen Pendidikan Nasional, 2002, Kamus Besar Bahasa Indonesia, Balai Pustaka, Jakarta

Hadiman, 2005, Pengawasan Serta Peran Aktif Orang Tua dan Aparat Dalam Penanggulangan Dari Penyalahgunaan Narkoba, Badan Kejaksaan Sosial Usaha Pembinaan Warga Tama (BERSAMA), Jakarta Makarau Moh. Taufik, dkk, 2003, Tindak Pidana Narkotika, Ghalia Indonesia, Jakarta

Mardani, 2008, Penyalahgunaan Narkoba Dalam Perspektif Hukum Islam dan Hukum Pidana Nasional, PT. Raja Grafindo Persada, Jakarta

Mulyadi, Lilik, 2012, Pemidanaan Terhadap Pengedar dan Pengguna Narkoba, Litbang Diklat MARI, Jakarta

Norman M. Garland, 2008, Criminal Law For The Criminal Justice Professional $M C$ - Grand - Hill, New York.

Rifai Achmad, 2014, Narkoba Dibalik Tembok Penjara, Aswaja Pressindo, Yogyakarta

Ronny Hamijoyo Sumantri, 2008, Metode Penelitian Hukum dan Yurimetri, Ghalia Indonesia, Jakarta 
Sunarso, Siswanto, 2011, Penegakan Hukum Psikotrpika Dalam Kajian Sosiologi Hukum. PT. Raja Grafindo Persada, Jakarta

Susetyo, Heru, dkk dan Nandi Widyani (ed), 2013, Sistem Pembinaan Narapidana Berdasarkan Prinsip Restorative Justice, BPHN - KEM - HUK - HAM, RI, Jakarta

UU RI No. 8 Tahun 1981 tentang KUHAP

UU RI No. 12 Tahun 1995 tentang Pemasyarakatan

UU RI No. 2 Tahun 2002 tentang Kepolisian Negara RI

UU RI No. 35 Tahun 2009 tentang Narkotika

PP RI No. 40 Tahun 2013 tentang Pelaksanaan UU No. 35 Tahun 2009 tentang Narkotika 